\title{
Analysis of the evolution and determinants of income-related inequalities in the Brazilian health system, 1998-2008
}

\author{
Gisele Almeida, ${ }^{1}$ Flavia Mori Sarti, ${ }^{2}$ Fernando Fagundes Ferreira, ${ }^{2}$ \\ Maria Dolores Montoya Diaz, ${ }^{3}$ and Antonio Carlos Coelho Campino ${ }^{3}$
}

Suggested citation Almeida G, Sarti FM, Ferreira FF, Diaz MDM, Campino ACC. Analysis of the evolution and determinants of income-related inequalities in the Brazilian health system, 1998-2008. Rev Panam Salud Publica. 2013;33(2):90-7.

ABSTRACT Objective. To analyze the evolution and determinants of income-related inequalities in the Brazilian health system between 1998 and 2008.

Methods. Data from the National Household Sampling Surveys of 1998, 2003, and 2008 were used to analyze inequalities in health and health care. Health was measured by self-reported health status, physical limitations, and chronic illness. Hospitalization and physician and dentist visits were proxies for health care utilization. Income was a proxy for socioeconomic status. Concentration indices were calculated before and after standardization for all dependent variables. Decomposition analysis was used to identify the main determinants of inequality in health care utilization.

Results. In all three periods analyzed, the poor reported worse health status, while the wealthy reported more chronic diseases; health care utilization was pro-rich for medical and dental services. Yet, income-related inequality in health care utilization has been declining. Private health insurance, education, and income are the major contributors to the inequalities identified.

Conclusions. Income-related inequality in the use of medical and dental health care is gradually declining in Brazil. The decline is associated with implementation of pro-equity policies and programs, such as the Community Health Agents Program and the Family Health Program.

Key words Equity in access; equity in health; health systems; health policy; Brazil.

Since inception of the Brazilian Unified Health System (SUS) at the end of the 1980s, efforts have been made to ensure an inclusive public health system model based on decentralization to attain democratization and promote

\footnotetext{
${ }^{1}$ Pan American Health Organization, Washington, D.C., United States of America. Send correspondence to: Gisele Almeida, almeidag@paho.org

${ }^{2}$ Escola de Artes, Ciências e Humanidades, Universidade de São Paulo, São Paulo, Brazil.

${ }^{3}$ Faculdade de Economia, Administração e Contabilidade, Universidade de São Paulo, São Paulo, Brazil.
}

accountability. A number of investments and implementation plans have been introduced to decentralize management of health services to state and municipal levels, to afford local governments more power and resources, to provide better care, and to promote universal and equal access to health services (1-4).

A trend toward improving the health status of the population and providing better access to health services has been noted in the literature (5-7). Yet, health gains have not been equal for all
Brazilians and the gap between health status and utilization of health services by the poor and the rich remains wide. Results from a study conducted in 2001, using a methodologic approach similar to the one proposed here, suggested that health care use is disproportionally distributed according to health needs, benefiting those who are in the highest income quintiles. In other words, given their health needs, those in the lowest income quintiles of the population use health care services less than 
expected when compared with those in the highest quintiles (8). These results indicate the existence of important socioeconomic barriers to access and utilization of heath care, which continues to be a challenge to the health system, despite its universalism $(4,6)$.

Monitoring the magnitude and trends of income-related inequality in health status and utilization of health services, while examining possible determinants of such inequality, is crucial to inform existing health policies intended to promote equity and to eliminate persistent and unfair health and health care differentials among population groups. Implementation of public policies to address gaps in the health system is an important path toward achieving equity goals but not an end in itself. To ensure that these goals are achieved and policies are adjusted when needed, it is necessary to monitor and evaluate results associated with these policies and health system characteristics relevant to these goals.

Improving the availability of evidence that can inform these processes and identify trends and areas of improvement will greatly contribute to effective planning and policy making. This study aims to analyze the evolution of income-related inequalities in health status and health care utilization of the population from 1998 to 2008 and their determinants, using survey data representative at a national level to measure the magnitude and examine the direction of equity.

A milestone in conceptualization of the Brazilian health system was the Eloy Chaves Law of 1923, which regulated existing retirement and pension funds and provided health services to beneficiaries and their dependents through employment benefits. The provision of health services remained mostly privately funded and fragmented through the 1930s, despite the merging of individual funds into several retirement and pension institutes. Creation of the Ministry of Health in the 1950s was not able to solve the remarkable disconnect between the national health system priorities and population health needs in the country $(1,9-11)$.

The national health system established during the military government was characterized by the creation, in 1966, of the National Social Security Institute, a public institution that centralized pensions and social security funds to finance private medical services for formal urban workers. During the 1970s, the payment of private health services by the government through fee for services became a significant source of corruption (9). The proposal for major changes in health policies arose, strongly suggesting reforms in the health system and implementation of universal health care.

The mid-1980s gave way to a redemocratization process in the country, but no significant changes occurred in the health system until an amendment was added to the Brazilian Constitution in 1988, which created the SUS and defined health as citizens' right and government's duty, guaranteed by social and economic policies to reduce the risk of disease and to support universal and equal access to health services that promote, protect, and recover health $(1,11)$.

Before implementation of the SUS, the responsibilities ascribed to the Ministry of Health were strictly related to activities that promote health and prevent disease in the population, such as vaccination campaigns and medical and hospital care for a few diseases, serving mostly the very poor and those without access to health care through the National Social Security Institute $(9,11)$. The diseaseoriented medical care model at that time explains the near absence of preventive care in the service delivery system.

Today, the Brazilian health system consists of a public and a private health system, which are intertwined and complex. Health services are provided through the SUS and are free at the point of service; private services are provided through private providers to those with private insurance, which is usually employment based or privately financed. To complement its services, the SUS contracts health services from private providers to deliver publicly financed health services to the population.

The SUS, in principle, provides universal access to health care to the entire population, including primary, secondary, and tertiary care; dental health services; prescription drugs; and diagnostic and therapeutic services. Management and administration of the SUS is shared at the federal, state, and municipal levels, according to the decentralization processes. The SUS is supported by community participation in its organization and management and is regulated by a set of laws and operational norms established to create a funding structure and obligations for the system at the federal, state, and municipal levels based on a decentralization model and performance-based incentives (12-14).

Because of inadequate infrastructure, shortage of specialized human resources, and funding differences among the Brazilian regions that existed for decades before the SUS was implemented, the decentralization process has been unable to reduce major disparities in the supply and quality of health care provided to the population. These regional disparities continue to pose a challenge to management of the system and delivery of services $(2,15-17)$.

There has been a generalized increase in private insurance coverage during the past three decades (18). Approximately $76 \%$ of the population receives publicly financed health services exclusively through the SUS, which also provides public services to those covered by private insurance, especially for complex and costly procedures. About $24 \%$ of the population is covered by private insurance through an employer or self-coverage. Distribution of private insurance coverage is uneven, with $60 \%$ concentrated in the southeastern region, the richest in the country (7). Approximately 83\% of Brazilian households in the highest per capita group (earning more than five times the minimum wage ${ }^{4}$ ) is covered by private health insurance, while private coverage for households in the lowest income group (earning one-quarter of the minimum wage) is only $2.3 \%$ (19).

\section{MATERIALS AND METHODS}

Using the methods described in the preceding article in this issue, this study analyzes data from the National Household Sample Survey (PNAD) conducted by the Brazilian Institute for Geography and Statistics. PNAD consists of household and individual-level surveys carried out annually by the Brazilian Institute for Geography and Statistics since the 1960s. Every five years, beginning in 1998, the population survey has been accompanied by a thematic module designed to collect information on the health conditions of the population. This study examined de-

\footnotetext{
$\overline{4}$ The minimum wage was created by the 1934 Brazilian Constitution to protect workers against excessively low wages. In 1988, the new Constitution redefined the minimum wage to provide for the essential needs of a family, including housing, food, education, health, leisure, clothing, hygiene, transportation, and social security, and calling for its periodic adjustment to preserve purchasing power.
} 
mographic, socioeconomic, health status, and health care utilization data from the 1998, 2003, and 2008 surveys, which included a health module.

The household samples surveyed are nationally representative. The PNAD sample is based on population projections from the Brazilian Demographic Census and may be extended to represent the population by using expansion factors. These samples were collected in a three-stage probabilistic sampling process: municipalities, census sectors, and household samples. For each year of the PNAD data collection, the sample varies according to the expansion factors applied (strata, sample weight, and cluster) and the legal definition of urban and rural settings, both of which are based on the previous demographic census (20).

With regard to the health module, changes in data collection related to chronic diseases from 1998 and the following surveys were introduced. In 1998, the survey requested information on chronic diseases reported by individuals, including or not including those conditions diagnosed by a health professional. For the 2003 and 2008 surveys, the question was changed to include only chronic conditions reported by individuals as those diagnosed by a health professional. This change in the survey question for chronic diseases compromised the comparability of this variable between 1998 and the following years, since the patterns of response from the poorest and richest quintiles have also changed, probably because of differential access to health care services in these groups. Therefore, chronic disease is analyzed in the study but is not included as a health care need variable for measuring inequity in health care utilization.

The 1998 PNAD database includes information from 344975 individuals in 90913 households, while the 2003 and 2008 PNAD databases include information from 384834 and 391868 individuals in 107846 and 118138 households, respectively (20). As described in Table 1 , variables selected from all three databases for the analysis of equity include age, sex, race, educational attainment, activity status, household income, number of household residents, family type, area and region of residence, health insurance coverage, self-assessed health status, physical limitations, chronic diseases, probability and number of physician visits, probability of dentist visits,

TABLE 1. Description of variables for analysis of health equity, National Household Sample Survey, Brazil, 1998, 2003, and 2008

\begin{tabular}{|c|c|}
\hline Variable & Description \\
\hline \multicolumn{2}{|l|}{ Health status } \\
\hline Self-assessed health & $\begin{array}{l}\text { Categorical: in general, how do you rate your own health status: } 1 \text {, very good; } \\
2 \text {, good; } 3 \text {, fair; } 4 \text {, poor; or } 5 \text {, very poor. }\end{array}$ \\
\hline Physical limitation & $\begin{array}{l}\text { Categorical: do you usually have difficulty, due to a health problem, in: } 1 \text {, } \\
\text { eating, taking a shower/bath, using the bathroom; } 2 \text {, running, lifting heavy } \\
\text { objects, practicing sports, or working in a strenuous task; } 3 \text {, pushing a table or } \\
\text { fixing things around the house; } 4 \text {, walking uphill or climbing stairs; } 5 \text {, bending, } \\
\text { squatting, or kneeling; } 6 \text {, walking more than } 1 \text { kilometer; or } 7 \text {, walking } 100 \\
\text { meters. For each question, possible answers include: } 1 \text {, cannot perform the } \\
\text { task; } 2 \text {, severe limitation; } 3 \text {, some limitation; and } 4 \text {, no limitation. }\end{array}$ \\
\hline Chronic illness & $\begin{array}{l}\text { Categorical: do you have any of the following chronic physical or mental health } \\
\text { problems? } 1 \text {, back pain; } 2 \text {, arthritis or rheumatism; } 3 \text {, cancer; } 4 \text {, diabetes; } \\
5 \text {, bronchitis or asthma; } 6 \text {, hypertension; } 7 \text {, heart disease; } 8 \text {, chronic renal } \\
\text { disease; } 9 \text {, depression; } 10 \text {, tuberculosis; } 11 \text {, tendinitis; or } 12 \text {, cirrhosis. Yes or } \\
\text { no. }\end{array}$ \\
\hline \multicolumn{2}{|l|}{ Health care utilization } \\
\hline Physician visits & $\begin{array}{l}\text { Categorical: did you have any physician consultation during the past } 12 \\
\text { months? Yes or no. Numeric count: how many times have you consulted a } \\
\text { physician during the past } 12 \text { months? }\end{array}$ \\
\hline Dentist visits & $\begin{array}{l}\text { Categorical: when did you last consult with a dentist? } 1 \text {, within the past year; } 2 \text {, } \\
1 \text { to } 2 \text { years ago; } 3,3 \text { years or longer; or } 4 \text {, never. }\end{array}$ \\
\hline Hospitalization & $\begin{array}{l}\text { Categorical: did you have any hospitalization during the past } 12 \text { months? Yes } \\
\text { or no. Numeric count: during the past } 12 \text { months, how long were you interned } \\
\text { in your last hospitalization? }\end{array}$ \\
\hline \multicolumn{2}{|l|}{ Standard of living } \\
\hline Income & Continuous: household income per month per adult equivalent. \\
\hline Race/ethnicity & $\begin{array}{l}\text { Categorical: self-defined race/ethnicity: } 1 \text {, white; } 2 \text {, black; } 3 \text {, mixed; } 4 \text {, oriental; } \\
\text { or } 5 \text {, indigenous. }\end{array}$ \\
\hline Education & $\begin{array}{l}\text { Categorical: highest level of education attained? 1, none; } 2 \text {, primary; } 3 \text {, } \\
\text { secondary; or } 4 \text {, post-secondary. }\end{array}$ \\
\hline Education years & Numeric count: how many years of education have you had? \\
\hline Geographic region & $\begin{array}{l}\text { Categorical: geographic area of residence: 1, North; } 2 \text {, Northeast; } 3 \text {, South; } 4 \text {, } \\
\text { Southeast; or 5, Midwest. }\end{array}$ \\
\hline Area of residence & Categorical: area of residence: 1 , urban; or 2 , rural. \\
\hline Family type & $\begin{array}{l}\text { Categorical: type of family: } 1 \text {, couple without children; } 2 \text {, couple with children; } 3 \text {, } \\
\text { single-parent home; or } 4 \text {, other family type. }\end{array}$ \\
\hline Economic activity & $\begin{array}{l}\text { Categorical: } 1 \text {, employed; } 2 \text {, unemployed; } 3 \text {, self-employed; } 4 \text {, housework; } 5 \text {, } \\
\text { retired; } 6 \text {, student; or } 7 \text {, other. }\end{array}$ \\
\hline Private health insurance & Categorical: yes or no. \\
\hline Household size & Numeric count: number of household residents. \\
\hline
\end{tabular}

probability of hospitalization, and number of inpatient days.

Household data were merged into the individual database for each period analyzed, and key matching variables were used. All variables with missing values expressed numerically were recoded into missing data. Household income was converted into household income per capita in adult equivalents, as explained in the introductory methodologic article in this issue. In order to avoid problems with analysis and to improve comparability among countries, which collect data on different age groups, only data from those 18 years of age or older were used.

\section{RESULTS}

For each health status and health services utilization variable studied, the quintile distribution, concentration curve, and concentration index are presented. Analysis of the PNAD databases and variables in Table 2 confirms demographic trends described in the literature that the population is getting older, is better educated, and is enjoying higher rates of employment (21).

In terms of health status, as noted in Table 3, individuals from lower income quintiles in general reported worse health status and severe physical difficulties more frequently than higher in- 
TABLE 2. Descriptive statistics from National Household Sample Survey, Brazil, 1998, 2003, and 2008

\begin{tabular}{|c|c|c|c|c|c|c|}
\hline \multirow[b]{2}{*}{ Variable } & \multicolumn{2}{|c|}{1998} & \multicolumn{2}{|c|}{2003} & \multicolumn{2}{|c|}{2008} \\
\hline & No. & $\%$ & No. & $\%$ & No. & $\%$ \\
\hline \multicolumn{7}{|l|}{ Age (years) } \\
\hline $18-34$ & 95168 & 45.6 & 110185 & 44.8 & 108687 & 41.7 \\
\hline $35-44$ & 44668 & 21.4 & 51477 & 20.9 & 53719 & 20.6 \\
\hline $45-64$ & 49746 & 23.8 & 61146 & 24.8 & 70875 & 27.2 \\
\hline $65-74$ & 12368 & 5.9 & 14818 & 6.0 & 16875 & 6.5 \\
\hline$>75$ & 6628 & 3.2 & 8493 & 3.4 & 10293 & 4.0 \\
\hline \multicolumn{7}{|l|}{ Sex } \\
\hline Male & 99399 & 47.6 & 117174 & 47.6 & 123864 & 47.6 \\
\hline Female & 109210 & 52.4 & 129012 & 52.4 & 136585 & 52.4 \\
\hline \multicolumn{7}{|l|}{ Health status } \\
\hline Very poor & 1955 & 0.9 & 1989 & 0.8 & 2578 & 10 \\
\hline Poor & 9194 & 4.4 & 9684 & 3.9 & 10623 & 4.1 \\
\hline Fair & 48706 & 23.4 & 57670 & 23.4 & 62482 & 24.0 \\
\hline Good & 104101 & 49.9 & 128700 & 52.3 & 137618 & 52.8 \\
\hline Very good & 44598 & 21.4 & 48118 & 19.5 & 47148 & 18.1 \\
\hline \multicolumn{7}{|l|}{ Physical limitations } \\
\hline None & 144572 & 69.3 & 174777 & 71.0 & 179180 & 68.8 \\
\hline Moderate & 51858 & 24.9 & 57480 & 23.3 & 63349 & 24.3 \\
\hline Severe & 12179 & 5.8 & 13929 & 5.7 & 17920 & 6.9 \\
\hline \multicolumn{7}{|l|}{ Chronic disease } \\
\hline None & 115878 & 55.5 & 148295 & 60.2 & 156612 & 60.1 \\
\hline Any & 92731 & 44.5 & 97891 & 39.8 & 103837 & 39.9 \\
\hline \multicolumn{7}{|l|}{ Race } \\
\hline White & 110927 & 53.2 & 121847 & 49.5 & 119728 & 46.0 \\
\hline Black & 13280 & 6.4 & 16830 & 6.8 & 21171 & 8.1 \\
\hline Oriental & 950 & 0.5 & 1007 & 0.4 & 1365 & 0.5 \\
\hline Mixed & 82981 & 39.8 & 105956 & 43.0 & 117308 & 45.0 \\
\hline Indigenous & 471 & 0.2 & 546 & 0.2 & 877 & 0.3 \\
\hline \multicolumn{7}{|l|}{ Education } \\
\hline No education & 44391 & 21.3 & 53477 & 21.7 & 47353 & 18.2 \\
\hline Primary & 101619 & 48.7 & 104185 & 42.3 & 97108 & 37.3 \\
\hline Secondary & 20163 & 9.7 & 25760 & 10.5 & 31000 & 11.9 \\
\hline High school or more & 42436 & 20.3 & 62764 & 25.5 & 84988 & 32.6 \\
\hline \multicolumn{7}{|l|}{ Activity status } \\
\hline Employed & 200154 & 95.9 & 234260 & 95.2 & 250568 & 96.2 \\
\hline Unemployed & 8455 & 4.1 & 11926 & 4.8 & 9881 & 3.8 \\
\hline Housework & 11863 & 5.7 & 14667 & 6.0 & 14878 & 5.7 \\
\hline Self-employed & 29770 & 14.3 & 35050 & 14.2 & 36254 & 13.9 \\
\hline Other & 344 & 0.2 & 380 & 0.2 & 643 & 0.2 \\
\hline Student & 9914 & 4.8 & 14143 & 5.7 & 10976 & 4.2 \\
\hline Retired & 21569 & 10.3 & 26387 & 10.7 & 28271 & 10.9 \\
\hline \multicolumn{7}{|l|}{ Private health insurance } \\
\hline No & 153253 & 73.5 & 182465 & 74.1 & 190654 & 73.2 \\
\hline Yes & 55338 & 26.5 & 63709 & 25.9 & 69795 & 26.8 \\
\hline \multicolumn{7}{|l|}{ Location } \\
\hline Urban & 173772 & 83.3 & 213195 & 86.6 & 222256 & 85.3 \\
\hline Rural & 34837 & 16.7 & 32991 & 13.4 & 38193 & 14.7 \\
\hline \multicolumn{7}{|l|}{ Geographic region } \\
\hline North & 14558 & 7.0 & 25173 & 10.2 & 31251 & 12.0 \\
\hline Northeast & 62706 & 30.1 & 77411 & 31.4 & 81757 & 31.4 \\
\hline Midwest & 22553 & 10.8 & 26791 & 10.9 & 28758 & 11.0 \\
\hline South & 36619 & 17.6 & 40612 & 16.5 & 40065 & 15.4 \\
\hline Southeast & 72173 & 34.6 & 76199 & 31.0 & 78618 & 30.2 \\
\hline Family type & & & & & & \\
\hline Couple without child & 25059 & 12.0 & 32397 & 13.2 & 40411 & 15.5 \\
\hline Couple with child & 133606 & 64.0 & 149645 & 60.8 & 149869 & 57.5 \\
\hline Mother with child & 29957 & 14.4 & 38427 & 15.6 & 40628 & 15.6 \\
\hline Other & 19987 & 9.6 & 25717 & 10.4 & 29541 & 11.3 \\
\hline Household size & 3.90 & & 3.68 & & 3.51 & \\
\hline
\end{tabular}

come individuals. It is noteworthy that all the income groups reported worse health status in 2008 than in 2003. While individuals in higher income groups reported more chronic illness than in- dividuals in lower income groups in 2008 than in 2003 (Table 3), possibly as a result of better access to health care and perception of their health status, the trend in reported chronic illness has been a decrease for higher income groups and an increase for lower income groups. In 1998, in contrast, the poor reported more chronic illness than the rich. This discrepancy is probably due to the change in the survey question, which did not require a medical diagnosis in 1998 but included this requirement in 2003 and 2008. Therefore, the change observed from 1998 and following surveys is probably influenced by the change in the survey question, since lower income individuals tend to have less access to health professionals for diagnosis. Concentration curves for health outcomes available in supplementary material clearly illustrate the change in this variable. The health outcome curves for 1998 show a propoor distribution (above the equality line) for all three variables: presence of physical limitations, less than good self-assessed health, and presence of at least one chronic illness. For 2003 and 2008, the distribution of chronic illness has changed for both years, and both curves are very close to the equality line. In 2008, the chronic illness curve has crossed the equality line at the poorest $40 \%$ of the population. Concentration indices for less than good self-assessed health and physical limitation, as per Table 4, are not statistically significant. Concentration indices for chronic illness are statistically significant and pro-rich for 2003 (0.0514) and 2008 (0.0482), but the difference between those years is not statistically significant.

Differences in the probability and intensity of use of physician visits, inpatient days, and probability of dentist visits among individuals from diverse socioeconomic groups decreased slowly over the period analyzed. Concentration curves for health care utilization in 1998, 2003, and 2008 illustrate this decline (see supplementary material). All utilization variables except the probability of hospitalization show a pro-rich distribution curve below the equality line. The curve for probability of hospitalization is very close to the equality line for most of the distribution and crosses the equality line for all years. From 1998 to 2008, the distance between all health care utilization curves and the equality line diminished, indicating less inequality over time. The trend observed with the concentration curves is confirmed by the standardized concentration indices (horizontal indi- 
TABLE 3. Standardized quintile distributions of health and health care variables, National Household Sample Survey, Brazil, 1998, 2003, and 2008

\begin{tabular}{|c|c|c|c|c|c|c|c|}
\hline \multirow[b]{2}{*}{ Variable } & \multirow[b]{2}{*}{ Year } & \multirow[b]{2}{*}{ Mean } & \multicolumn{5}{|c|}{ Quintile } \\
\hline & & & Poorest & Second & Third & Fourth & Richest \\
\hline \multicolumn{8}{|l|}{ Health status } \\
\hline \multirow{3}{*}{$\begin{array}{l}\text { Less than good self- } \\
\text { assessed health }\end{array}$} & 1998 & 0.2870 & 0.3586 & 0.3640 & 0.2997 & 0.2461 & 0.1666 \\
\hline & 2003 & 0.2817 & 0.3485 & 0.3380 & 0.3140 & 0.2458 & 0.1622 \\
\hline & 2008 & 0.2906 & 0.3630 & 0.3410 & 0.3227 & 0.2545 & 0.1718 \\
\hline \multirow[t]{3}{*}{ Any physical limitation } & 1998 & 0.3070 & 0.3467 & 0.3679 & 0.3110 & 0.2739 & 0.2354 \\
\hline & 2003 & 0.2901 & 0.3047 & 0.3202 & 0.3170 & 0.2721 & 0.2363 \\
\hline & 2008 & 0.3120 & 0.3263 & 0.3436 & 0.3429 & 0.2985 & 0.2489 \\
\hline \multirow[t]{3}{*}{ Any chronic illness } & 1998 & 0.4445 & 0.4704 & 0.4817 & 0.4476 & 0.4216 & 0.4014 \\
\hline & 2003 & 0.3976 & 0.3537 & 0.3965 & 0.4130 & 0.4098 & 0.4151 \\
\hline & 2008 & 0.3987 & 0.3621 & 0.3986 & 0.4202 & 0.4086 & 0.4040 \\
\hline \multicolumn{8}{|l|}{ Health care utilization } \\
\hline \multirow[t]{3}{*}{ Any doctor visit } & 1998 & 0.5848 & 0.5185 & 0.5598 & 0.5685 & 0.6006 & 0.6763 \\
\hline & 2003 & 0.6459 & 0.5742 & 0.6088 & 0.6346 & 0.6668 & 0.7452 \\
\hline & 2008 & 0.6964 & 0.6339 & 0.6660 & 0.6911 & 0.7134 & 0.7774 \\
\hline \multirow{3}{*}{$\begin{array}{l}\text { Total number of doctor } \\
\text { visits }\end{array}$} & 1998 & 2.3928 & 2.0079 & 2.2932 & 2.3360 & 2.4912 & 2.8358 \\
\hline & 2003 & 2.7156 & 2.3643 & 2.5415 & 2.6607 & 2.8029 & 3.2088 \\
\hline & 2008 & 3.0332 & 2.7120 & 2.8667 & 3.0265 & 3.0919 & 3.4691 \\
\hline \multirow[t]{3}{*}{ Any hospitalization } & 1998 & 0.0839 & 0.1014 & 0.0929 & 0.0794 & 0.0730 & 0.0728 \\
\hline & 2003 & 0.0807 & 0.0926 & 0.0825 & 0.0780 & 0.0732 & 0.0770 \\
\hline & 2008 & 0.0794 & 0.0891 & 0.0816 & 0.0776 & 0.0731 & 0.0757 \\
\hline \multirow{3}{*}{$\begin{array}{l}\text { Total number of inpatient } \\
\text { days }\end{array}$} & 1998 & 0.5409 & 0.6241 & 0.6460 & 0.5644 & 0.4551 & 0.4150 \\
\hline & 2003 & 0.5086 & 0.5761 & 0.4933 & 0.5292 & 0.4740 & 0.4701 \\
\hline & 2008 & 0.5557 & 0.5967 & 0.5882 & 0.5818 & 0.5093 & 0.5027 \\
\hline \multirow[t]{3}{*}{ Any dentist visit } & 1998 & 0.3316 & 0.1991 & 0.2337 & 0.2947 & 0.3817 & 0.5489 \\
\hline & 2003 & 0.3771 & 0.2518 & 0.2868 & 0.3297 & 0.4247 & 0.5927 \\
\hline & 2008 & 0.3900 & 0.2917 & 0.3108 & 0.3464 & 0.4260 & 0.5749 \\
\hline
\end{tabular}

ces) for 1998, 2003, and 2008 (Table 4), indicating historic changes related to a reduction in income-related inequalities in the utilization of health care services over time, specifically for probability of physician visits $(0.072,0.065$, and 0.052$)$, total number of physician visits $(0.120$, 0.103 , and 0.087 ), and probability of dentist visits $(0.227,0.199$, and 0.159$)$. The horizontal indices for inpatient days and probability of hospitalization were not statistically significant for the three years studied. All other horizontal index utilization variables were statistically signifi- cant as well as their difference over time (see Table 4).

Figure 1 presents the results of decomposition analysis for all statistically significant utilization variables. Decomposition revealed the major determinants of income-related inequality (horizontal index) in health care utilization to be private health insurance, household income, and education attainment in general. Private health insurance coverage was the major determinant of inequity for probability and intensity of physician visits, followed by income and education. In the case of probability of dentist visits, major contributors were income and education, followed by private health insurance coverage. Region of the country and area of residence also contributed to inequity in utilization of health care, especially for physician visits. This situation is probably due to the infrastructure differences between regions and urban and rural areas, as hypothesized. Models testing the influence of states within each region as determinants of income-related inequality in health care utilization did not show a significant difference.

TABLE 4. Concentration indices for health status and health care utilization variables, National Household Sample Survey, Brazil, 1998, 2003, and 2008

\begin{tabular}{|c|c|c|c|c|c|c|c|c|}
\hline \multirow[b]{2}{*}{ Variable } & \multicolumn{2}{|c|}{1998} & \multicolumn{2}{|c|}{2003} & \multicolumn{2}{|c|}{2008} & \multicolumn{2}{|c|}{ HI difference } \\
\hline & $\mathrm{Cl}$ & $\mathrm{HI}$ & $\mathrm{Cl}$ & $\mathrm{HI}$ & $\mathrm{Cl}$ & $\mathrm{HI}$ & 1998-2003 & 2003-2008 \\
\hline Self-assessed health (less than good) & -0.1460 & -0.1064 & -0.1432 & -0.1333 & -0.1408 & -0.1312 & $-0.0270^{a}$ & $0.0022^{a}$ \\
\hline Physical limitation (any) & -0.0880 & -0.0398 & -0.0591 & -0.0420 & -0.0571 & -0.0385 & $-0.0022^{a}$ & $0.0035^{a}$ \\
\hline Chronic illness (any) & -0.0397 & 0.0028 & $0.0252^{a}$ & $0.0514^{a}$ & $0.0185^{a}$ & $0.0482^{a}$ & $0.0486^{a}$ & -0.0032 \\
\hline Physician visits (probability) & $0.0514^{a}$ & $0.0724^{a}$ & $0.0518^{a}$ & $0.0653^{a}$ & $0.0398^{a}$ & $0.0518^{a}$ & $-0.0071^{\mathrm{a}}$ & $-0.0135^{a}$ \\
\hline Physician visits (total) & $0.0656^{a}$ & $0.1200^{a}$ & $0.0581^{a}$ & $0.1030^{a}$ & $0.0429^{a}$ & $0.0868^{a}$ & $-0.0170^{a}$ & $-0.0162^{a}$ \\
\hline Hospitalization (probability) & -0.0767 & -0.0104 & -0.0470 & 0.0128 & -0.0411 & 0.0189 & $0.0231^{a}$ & 0.0061 \\
\hline Hospitalization (days) & -0.0856 & 0.0239 & -0.0367 & 0.0623 & -0.0413 & 0.0430 & $0.0383^{a}$ & $-0.0192^{a}$ \\
\hline Dentist visits (probability) & $0.2228^{a}$ & $0.2266^{a}$ & $0.1873^{a}$ & $0.1988^{a}$ & $0.1472^{a}$ & $0.1590^{a}$ & $-0.0278^{a}$ & $-0.0398^{a}$ \\
\hline
\end{tabular}

$\mathrm{Cl}$ : concentration index, $\mathrm{HI}$ : horizontal index.

a Significant $\mathrm{Cl}$ and $\mathrm{HI}$ indices $(P<0.05)$. 
FIGURE 1. Decomposition of income-related inequality (horizontal index) in health care utilization, National Household Sample Survey, Brazil, 1998, 2003, and 2008

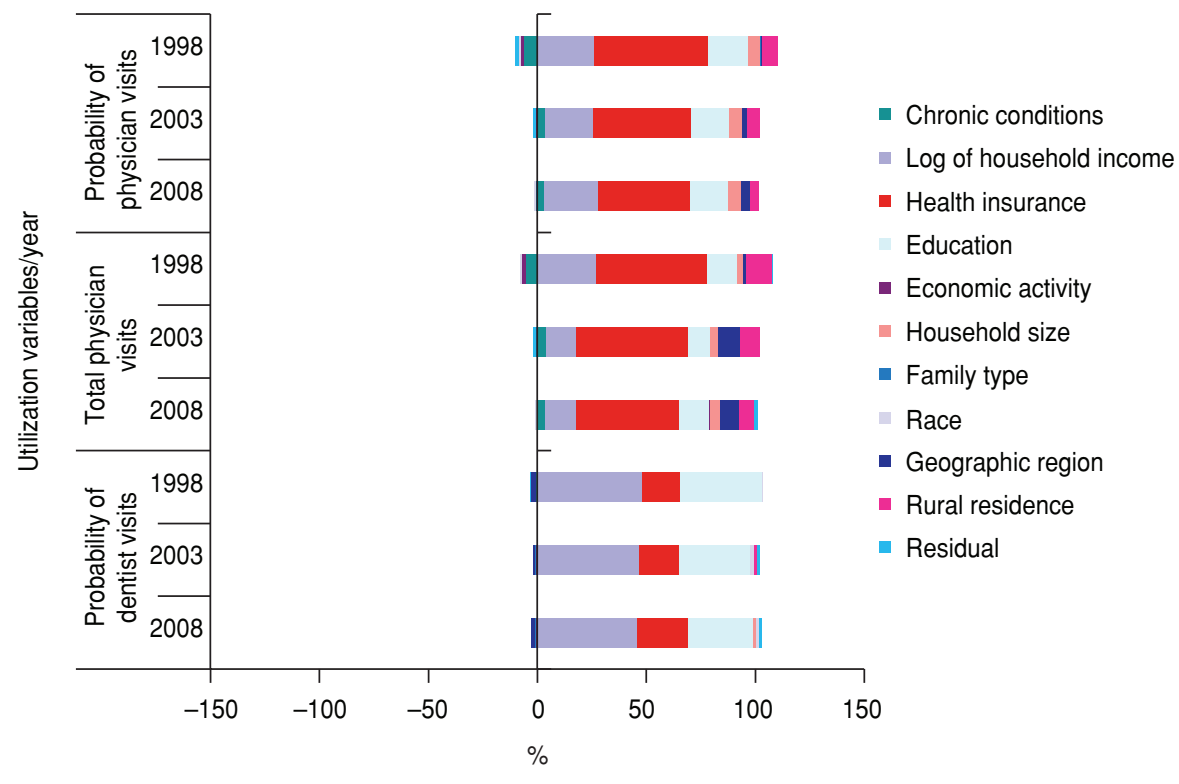

\section{DISCUSSION}

The results of quintile distributions in Table 3 indicate that the Brazilian population reported worse health status and more physical limitations in 2008 than in 2003. Concentration indices for these variables (Table 4) are not statistically significant for all years studied, which limits the interpretation of trends in terms of equity over time for these variables. Quintile distributions of chronic illness show an increase in the first three quintiles and a decrease in the fourth and fifth quintiles from 2003 to 2008 . These results are supported by pro-rich concentration indices for chronic illness for both years, although the trend between 2003 and 2008 is not clear given that the difference between these two years is not statistically significant.

A positive trend is observed in reference to equity in utilization of health services from 1998 to 2008, probably due to consolidation of the public universal health system, which seems to have reached a degree of maturity after two decades of implementation (1988-2008). The observed decline in income-related inequalities for medical and dental services may have been influenced by improved access to these services for the population, mostly the poor, through public programs such as the Community Health Agents Program and the Family
Health Program. These programs have been implemented in most municipalities and seek to promote enhanced access to health care, promoting better life conditions and the use of preventive care in the population. From 1994 to 2002, the country witnessed an aggressive expansion in coverage for the Community Health Agents Program and the Family Health Program, reaching 53\% and 34\% of the population, respectively. Coverage in these programs continued to grow from 2002 and 2008 but at a much reduced rate, with population coverage reaching $61 \%$ and $49 \%$, respectively. This expansion was inversely related to infant mortality rates in the country, which declined from 34 per 1000 live births in 1994 to 16 per 1000 in 2006 (19).

Findings reported in this study are supported by evidence from other studies in the literature $(5,22,23)$. Although the evidence here suggests that incomerelated inequalities in utilization of medical and dental services are slowly declining in the country, these inequalities remain significant. In other words, the gap between the rich and poor is still large, with the poor reporting lower health status and more health problems than the rich and yet utilizing fewer health services. Given the universality of the Brazilian health system, it may be mistakenly suggested that individuals' behavior toward health care may contribute to the existing inequity. Nevertheless, an individual's behavior is closely linked to characteristics of the health system such as quality, supply, and distribution of services (24). Considering that access problems are actually mentioned by the population as a barrier to enrolling in social protection programs, an individual's behavior toward health care utilization does not seem to be the most plausible explanation for the existing gap $(25,26)$.

The results of this study also shed some light on the conditions underlying the promotion of pseudo-universal access to health care. Approximately $75 \%$ of the population relies solely on the public health system, while only $25 \%$ of the population (those in higher income strata) has private health insurance coverage. This scenario illustrates the level of segmentation of the Brazilian health system, which contributes to income-related inequality in health and health care utilization. Inequalities in the supply and utilization of health services benefiting the rich and those with private insurance have been confirmed by other studies $(22,27)$.

This study presents important limitations that should be noted, including the use of self-reported information, specifically for health outcomes and health care utilization measures; changes introduced in the survey question for chronic diseases, which made comparison over time difficult; and lack of variables to assess quality of health care, which affect access and utilization of health care services. Self-reported health measures are themselves determined by health care utilization. Therefore, individuals with low levels of utilization are less likely to report health conditions that otherwise would be diagnosed, such as chronic diseases. Some bias may also exist due to differences in the actual and reported health status of individuals, which are influenced by different expectations for health, different cognitive processes, variations among socioeconomic groups, variations in cultural or gender norms, knowledge and information, or any other factor that may influence respondents' perceptions and understanding of their health problems (28). While the survey provides a wealth of information on personal and household characteristics, it was not designed primarily to test equity in health and health care. The available data and the methods used for 
this study are limited to information on differences in quantities of health care utilization; therefore, the quality or appropriateness of health care cannot be assessed. Given the importance of health care quality to access and utilization of health services, dimensions ascribed to health care quality should be investigated. Regrettably, PNAD does not include sufficient quality measures to make such an assessment.

Despite these potential biases, the use of a very large sample size in this study provides high-precision estimates. In addition, these results are to be interpreted as a single dimension of socioeconomic inequalities in health and utilization of health care. Other methods should be used to complement and support these findings.

From a health policy perspective, this study provides important evidence of the direction of equity in the Brazilian health system over the 1998-2008 period, which can guide decision-making processes for the expansion and modification of policies and programs that have the potential to further reduce the still large income-related inequalities in health and health care utilization in the country. While the public health system seems to have had a positive impact on equity in health and health care since its creation, much remains to be done to ensure the ideal of universal access to health care.

To improve the evidence on equity and universality of the Brazilian health system, the results presented here should be complemented by studies on health care quality, health systems financing, outof-pocket expenditures, and catastrophic expenditures of Brazilian households.

Funding. This study was funded by the Equity in Health Systems in Latin America and the Caribbean (EquiLAC) Project of the Pan American Health Organization.

\section{Conflict of interest. None.}

\section{REFERENCES}

1. Lima NT, Fonseca CMO, Hochman G. A saúde na construção do estado nacional no Brasil: reforma sanitária em perspectiva histórica. In: Lima NT, Gerschman S, Edler FC, Suárez JM, eds. Saúde e democracia-história e perspectivas do SUS. Rio de Janeiro: Editora Fiocruz; 2005. Pp. 27-58.

2. Costa NR. A descentralização do sistema público de saúde no Brasil: balanço e perspectiva. In: Negri B, Di Giovanni G, eds. Brasil: radiografia da saúde. Campinas: Universidade Estadual de Campinas; 2001. Pp. 307-21.

3. Mobarak A, Rajkumar A, Cropper M. The political economy of health services provision and access in Brazil. Working paper. Washington, D.C.: World Bank; 2004.

4. Almeida C, Travassos C, Porto S, Labra M. Health sector reform in Brazil: a case study of inequity. Int J Health Serv. 2000;30(1):129-62.

5. Travassos C, Oliveira EXG, Viacava F. Desigualdades geográficas e sociais no acesso aos serviços de saúde no Brasil: 1998 e 2003. Cienc Saude Colet. 2006;11(4):975-86.

6. Pinheiro RS, Viacava F, Travassos C. Gênero, morbidade, acesso e utilização de serviços de saúde no Brasil. Cienc Saude Colet. 2002;7(4):687-707.

7. Pan American Health Organization. Health in the Americas. Vol. II. Washington, D.C.: PAHO; 2002. (Scientific and Technical Publication 587).

8. Campino A, Diaz M, Paulani L, Oliveira R, Piola S, Nunes, A. Health system inequalities and poverty in Brazil. In: Investment in health: social and economic returns. Washington, D.C.: PAHO; 2001. Pp. 143-60. (Scientific and Technical Publication 582).

9. Rodrigues P, Santos I. Saúde e cidadania: uma visão histórica e comparada do SUS. 1st ed. Rio de Janeiro: Editora Atheneu; 2008.

10. Nunes ED. Saúde coletiva: história de uma idéia e de um conceito. Saúde Soc. 1994;3(2): 5-21.

11. Escorel S, Nascimento DR, Edler FC. As origens da reforma sanitária e do SUS. In: Lima NT, Gerschman S, Edler FC, Suárez JM, eds. Saúde e democracia: história e perspectivas do SUS. Rio de Janeiro: Editora Fiocruz; 2005. Pp. 59-81.

12. Brasil, Ministério da Saúde. Norma operacional básica do distema único de saúde (NOB-SUS 1996). Brasília: Ministério da Saúde; 1996.

13. Brasil, Ministério da Saúde. Pacto pela saúde. Brasília: Ministério da saúde; 2002.

14. Negri B, Viana, ALD. O sistema único de saúde em dez anos de desafio. São Paulo: Sociedade Brasileira de Vigilância de Medicamentos: Centro de Estudos Augusto Leopoldo Ayrosa Galvão; 2002.

15. Bahia L. O SUS e os desafios da universalização do direito à saúde: tensões e padrões de convivência entre o público e o privado no sistema de saúde brasileiro. In: Lima NT, Gerschman S, Edler FC, Suárez JM, eds. Saúde e democracia: história e perspectivas do SUS. Rio de Janeiro: Editora Fiocruz; 2005. Pp. 407-50.

16. Arretche M, Marques E. Condicionantes locais da descentralização das políticas de saúde. In: Hochman G, Arretche M, Marques E, eds. Políticas públicas no Brasil. Rio de Janeiro: Editora Fiocruz; 2007. Pp. 173-204.

17. Rinne J. Mejorando el desempeño del sector salud en Brasil: comparación entre distintos modelos de hospitales. Rev CLAD Reforma Dem. 2007;37:101-40.

18. Diniz BPC, Servo LMS, Piola SF, Eirado M. Gasto das famílias com saúde no Brasil: evolução e debate sobre gasto catastrófico. In: Silveira FG, Servo LMS, Menezes T, Piola SF, eds. Gasto e consumo das famílias brasileiras contemporâneas. Vol. 2. Brasília: Instituto de Pesquisa Econômica Aplicada; 2007. Pp. 143-67.

19. Medici A. Propostas para melhorar a cobertura, a eficiência e a qualidade no setor saúde. In: Bacha EL, Schwartzman S, eds. Brasil: A nova agenda social. Rio de Janeiro: Editora LTC; 2011. Pp. 21-88.

20. Instituto Brasileiro de Geografia e Estatística. Pesquisa nacional por amostra de domicílios. Rio de Janeiro: Centro de Documentação e Disseminação de Informa-
ções/Instituto Brasileiro de Geografia e Estatística; 1998, 2003, and 2008.

21. Nishijima M, Biasoto G Jr. The health financing patterns in American countries. In: Biasoto G Jr., Silva PLB, Dain S, eds. Health sector regulation in Americas: relations among public and private in a systemic approach. Brasilia: PAHO; 2006. Pp. 107-40.

22. Guanais FC. Progress in a land of extremes. BMJ. 2010;341:1198-201.

23. Cataife G, Coutermanche C. Is universal health care in Brazil really universal? Available from: http://www.uncg.edu/bae/ people/courtemanche/documents/papers/brazil_HE.pdf Accessed 22 February 2011.

24. Paim J, Travassos C, Almeida C, MacInko J. The Brazilian health system: history, advances, and challenges. Lancet. 2011;377: 1778-97.

25. Instituto Polis. Pesquisa de opinião com beneficiários do Programa Bolsa Família. In: Vaitsman J, Paes-Sousa R, eds. Avaliação de políticas e programas do MDS: resultados. Volume II. Brasília: Ministério do Desenvolvimento Social e Combate à Fome; 2007.

26. Brasil Ministério da Saúde. As causas sociais das iniqüidades em saúde no Brasil. Brasília: Comissão Nacional sobre Determinantes Sociais da Saúde; 2008.

27. Santos IS, Ugá MAD, Porto SM. The public-private mix in the Brazilian Health System: financing, delivery and utilization of health services. Ciênc Saúde Colet. 2008;13(5): 1431-40.

28. Sadana R, Mathers CD, Lopez AD, Murray CJ, Iburg KM. Comparative analyses of more than 50 household surveys on health status. Geneva: World Health Organization; 2000.

Manuscript received on 1 March 2012. Revised version accepted for publication on 29 November 2012. 
RESUMEN Objetivos. Analizar la evolución y los determinantes de las desigualdades relacionadas con los ingresos en el sistema de salud brasileño entre 1998 y 2008.

Métodos. Se utilizaron los datos de la Encuesta Nacional de Hogares de 1998, 2003

Análisis de la evolución y los determinantes de las desigualdades relacionadas con los ingresos en el sistema de salud de Brasil, 1998-2008 y 2008. La salud se midió según el estado de salud autoevaluado, las limitaciones físicas y las enfermedades crónicas. Las hospitalizaciones y las consultas médicas y odontológicas se usaron como medición indirecta de la utilización de la atención sanitaria, y los ingresos para estimar el nivel socioeconómico. Los índices de concentración para todas las variables dependientes se calcularon antes y después de su estandarización. Se empleó análisis de descomposición para identificar los principales determinantes de desigualdad en la utilización de la atención sanitaria.

Resultados. En los tres períodos analizados, las personas con menor nivel socioeconómico informaron un peor estado de salud, mientras que las de mayor nivel informaron más enfermedades crónicas y tuvieron una mayor utilización de la atención sanitaria (servicios médicos y odontológicos). A pesar de esto, la desigualdad en la utilización de la atención sanitaria relacionada con los ingresos ha ido disminuyendo. El seguro de salud privado, la educación y los ingresos son los principales factores que contribuyen a las desigualdades identificadas.

Conclusiones. Las desigualdades en la utilización de los servicios médicos y odontológicos relacionadas con los ingresos han disminuido gradualmente en Brasil. Esta disminución se asoció con la aplicación en el país de políticas y programas que favorecen la equidad, como el Programa de Agentes de Salud Comunitarios y el Programa de Salud Familiar.

Palabras clave Equidad en el acceso; equidad en salud; sistemas de salud; política de salud; Brasil. 
REVISTA

PANAMERICANA

DE SALUD PÚBLICA
PAN AMERICAN

JOURNAL OF

PUBLIC HEALTH

Material suplementario / Supplementary material / Material supplementar

Supplementary material to:

Vásquez F, Paraje G, Estay M. Income-related inequality in health and health care utilization in Chile, 2000-2009. Rev Panam Salud Publica. 2013;33(2):98-106.

This material formed part of the original submission and has been peer reviewed. We post it as supplied by the authors. 

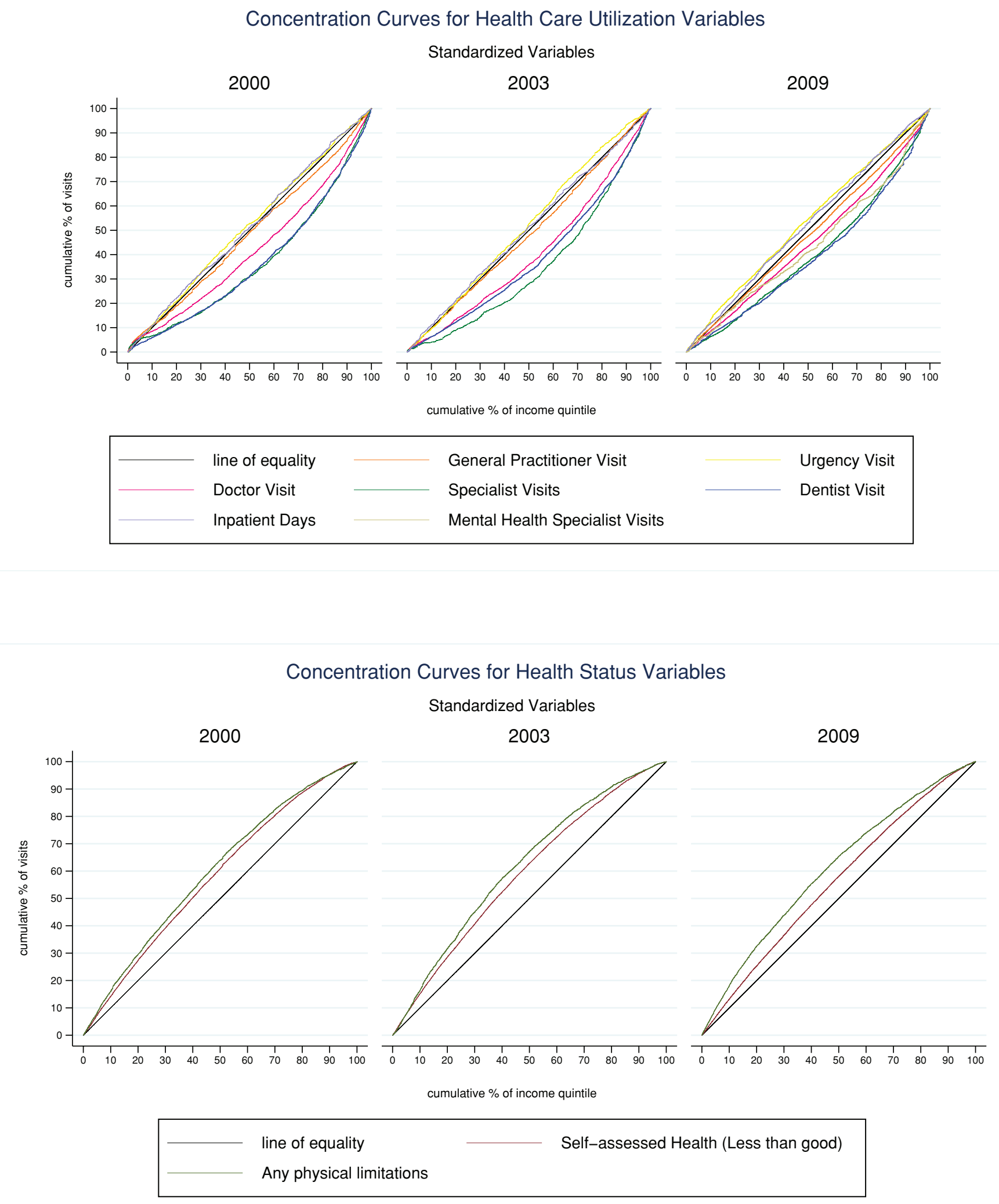